Ewa Kostrzewska

Uniwersytet Śląki w Katowicach

\title{
ZARZĄDZANIE NIERUCHOMOŚCIAMI W PROCESIE WDRAŻANIA ZRÓWNOWAŻONEGO ROZWOJU
}

\section{Wprowadzenie}

Zrównoważony rozwój jest podstawową konstytucyjną zasadą ustroju polskiego. Zgodnie bowiem z art. 5 Konstytucji RP „Rzeczpospolita Polska strzeże niepodległości swojego terytorium, zapewnia wolność i prawa człowieka i obywatela oraz bezpieczeństwo obywateli, strzeże dziedzictwa narodowego oraz zapewnia ochronę środowiska, kierując się zasadą zrównoważoneg o rozwoju".

Na uwagę zasługuje również fakt, że zrównoważony rozwój jest także zasadą ustrojową Wspólnoty Europejskiej.

Rozwój idei zrównoważonego rozwoju sięga dziewiętnastego i dwudziestego wieku, gdyż w tym okresie nastąpiło szereg negatywnych zjawisk środowiskowych, takich jak nadmierna eksploatacja zasobów naturalnych, degradacja i niszczenie ekosystemów.

Lata 60. i 70. XX w. to czas, kiedy zaczęto zastanawiać się nad skutkami nieograniczonego wzrostu gospodarczego. Pierwszym krokiem do dalszych czynności w tym zakresie było opisanie problemu i znalezienie racjonalnego rozwiązania.

J.S. Zegar podkreślał, że „człowiek osiągnął znaczny postęp cywilizacyjny za cenę niszczenia środowiska stanowiącego jego siedlisko. Zmiany w środowisku przekraczają bowiem zdolność ekosystemów do odnowy. Kontynuowanie tych zmian nieuchronnie prowadzi do regresu ekonomicznego (bariera środowiskowa), a zatem zagraża podstawom rozwoju cywilizacyjnego". (...) taki stan rzeczy jest wystarczający do zakwestionowania podstawowego paradygmatu rozwoju gospodarczego oraz w ogóle dotychczasowego rozwoju cywilizacyjnego ostatnich stuleci”. ${ }^{1}$

1 J.S. Zegar, Kierowanie zrównoważonym rozwojem społeczno-gospodarczym (ekorozwojem), „Monografie i Opracowania" 2003, nr 522, s. 9. 
Wyżej wskazane treści wskazują, że obecną sytuację rynkową należy postrzegać przez pryzmat kryzysu społecznego i środowiskowego. Wiąże się to $\mathrm{z}$ faktem zależności człowieka od przyrody, której ograniczone zasoby mogą przyczynić się w końcowym etapie do zahamowania rozwoju społeczno-gospodarczego.

Dlatego tak ważny jest rozwój zrównoważony, którego zagadnienie wpisuje się w problem racjonalnego gospodarowania zasobem nieruchomości.

Wynika to $\mathrm{z}$ faktu, że dobra naturalne, takie jak grunty leśne, cieki wodne $\mathrm{i}$ inne, stanowią nieruchomości gruntowe niezabudowane. Zmiana dóbr naturalnych, na przykład wycinka lasów, może prowadzić do nieodwracalnych procesów. Dodatkowo nieruchomości zabudowane generują zapotrzebowanie energetyczne, co powoduje konieczność degradacji innych nieruchomości, takich jak kopaliny, terenów pod wodne elektrownie. Dlatego w procesie gospodarowania nieruchomościami tak istotna jest instytucja zrównoważonego rozwoju.

\section{Prawidłowe gospodarowanie nieruchomościami jako podstawa wdrażania procesu zrównoważonego rozwoju}

E. Kozłowski definiuje pojęcie gospodarowania nieruchomościami jako proces odbywający się według regulacji prawa, a w szczególności w oparciu o art. 140 Kodeksu cywilnego, gdzie został określony zakres wykonywania prawa własności. ${ }^{2}$

W ustawie o samorządzie powiatowym czynnościami określającymi gospodarowanie są: 1) ewidencjonowanie nieruchomości, 2) przygotowanie opracowań geodezyjno-prawnych, 3) podejmowanie czynności w postępowaniach sądowych i administracyjnych dotyczących nieruchomości, 4) sporządzanie planu wykorzystania zasobu, 5) zapewnienie wykonywania wycen nieruchomości, 6) administracja i zabezpieczenie przed uszkodzeniem i zniszczeniem, 7) wnioskowanie i udział przy postępowaniu rozgraniczeniowym.

Przez gospodarowanie nieruchomościami należałoby również rozumieć wykonywanie czynności związanych z obrotem, transferem praw do nieruchomości (nabywanie, zbywanie, najem, leasing, dzierżawa, użytkowanie wieczyste) ${ }^{3}$

Gospodarowanie nieruchomościami winno być rozpatrywane zatem w dwóch ujęciach: skali makro (określenie roli państwa, tj. rządu i jednostek samorządu terytorialnego) oraz mikro (rola przedsiębiorstw profesjonalnie zarządzających nieruchomościami oraz zajmujących się dostarczaniem praw związanych z możliwością korzystania z nieruchomości - własności lub najmu).

\footnotetext{
2 Art. 140 Kodeksu cywilnego: „W granicach określonych przez ustawy i zasady współżycia społecznego właściciel może, z wyłączeniem innych osób, korzystać z rzeczy zgodnie ze społeczno-gospodarczym przeznaczeniem swego prawa, w szczególności może pobierać pożytki i inne dochody z rzeczy. W tych samych granicach może rozporządzać rzeczą."

3 Encyklopedia wiedzy o nieruchomościach, W. Baranowski, G. Buczek, B. Chełmiński, K. Jurek, E. Kozłowski, A. Nalepka, B. Rogatko, J. Schmidt (red.), Warszawa-Kraków 2008, s. 90.
} 
Powyższe definicje, niestety, nie odzwierciedlają procesów rynkowych oraz pozbawione są aspektów społecznych.

$\mathrm{Na}$ uwagę zasługuje bowiem fakt, że rolą gospodarowania zasobem nieruchomości jest nie tylko kwestia administracyjna ograniczająca się do kształtowania norm prawnych, ale również uwzględnienie ekonomicznego wykorzystania tego zasobu w celu poprawy jego społecznej jakości.

Wywieść $\mathrm{z}$ tej tezy można wniosek, że gospodarowanie nieruchomościami to nic innego, jak umiejętny i racjonalny system zarządzania, który będzie mieć na celu optymalne zaspokojenia stale rosnących potrzeb ludzkich przy jednoczesnym ich ograniczaniu z uwagi na uwarunkowania środowiska naturalnego.

Spostrzeżenie to prowadzi do traktowania obecnej sytuacji rynkowej na zasadach kryzysu i chaosu ekonomicznego w wymiarze społecznym i środowiskowym.

Kryzys ten w swoich publikacjach G. Dobrzański określa jako „taki stan powiązań i zależności między człowiekiem i przyrodą, który powoduje zmiany w środowisku mogące prowadzić do zahamowania rozwoju społeczno-gospodarczego i niezaspokojenia niektórych ważnych potrzeb ludzkich. ${ }^{4}$

$\mathrm{Na}$ uwagę zasługują trzy warianty rozwoju rynku nieruchomości w naszym kraju:

1) planistyczny prośrodowiskowy, w którym zwiększenie zasobu będzie wynikało, zaplanowania rozwoju uwzględniającego konieczność wykorzystania zasobów środowiska naturalnego z jednoczesną minimalizacją efektów ubocznych.

Zatem cele nadrzędne będą ściśle powiązane $\mathrm{z}$ minimalizacją utraty zasobów naturalnych, a z drugiej strony z koniecznością rozwoju zasobu nieruchomości - będzie to możliwe do zrealizowania na siedliskach o niskiej wartości ekologicznej.

2) planistyczny prorozwojowy, w którym zwiększenie zasobów będzie wynikało z zaplanowanego rozwoju uwzględniającego konieczność wykorzystania zasobów środowiska naturalnego, $\mathrm{z}$ jednoczesną maksymalizacją rozwoju zasobu nieruchomości.

Zatem cele nadrzędne będą realizowane przez pryzmat maksymalizacji zmierzającej do zwiększenia zasobów nieruchomości, co będzie się wiązało z utratą zasobów naturalnych - będzie to możliwe do zrealizowania na siedliskach w urbanistycznie uzasadnionych lokalizacjach.

3) chaotyczny, w którym zwiększenie zasobu będzie wynikało z nieplanowanego rozwoju nie uwzględniającego wykorzystania zasobów środowiska naturalnego w sposób racjonalny.

Co należy zrobić, aby zapobiec utracie ograniczonych zasobów naturalnych?

Po pierwsze należy przekształcić postęp technologiczny w taki sposób, aby zahamować spadek zużycia zasobów naturalnych. Zmiana w tym zakresie nie powinna 
być podyktowana przez modę, która niejednokrotnie kreuje sztuczne i nieuzasadnione potrzeby.

Tak więc drugi wskazany powyżej aspekt prośrodowiskowy winien być rozpatrywany przez pryzmat potrzeb przyszłych pokoleń, które również będą potrzebować do funkcjonowania organicznych zasobów naturalnych.

Uzyskanie tego rozwiązania jest (i będzie) bardzo trudne, ponieważ wiąże się to ze zmianami, jakie muszą nastąpić w samej świadomości ludzi. Obecnie bowiem jako członkowie Unii Europejskiej gonimy inne gospodarki tej Unii, nie zastanawiając się nad tym, że każda gospodarka rządzi się swoimi prawami.

Dlatego ważnym aspektem rozwoju zrównoważonego jest znalezienie wspólnych celów z rynkiem nieruchomości.

T. Borys dzieli cele na: 1) społeczne cele nadrzędne, takie jak dobrobyt, sprawiedliwość, bezpieczeństwo, 2) idealizacyjne, to jest utrzymanie funkcji ekologicznych środowiska przyrodniczego, 3) cele empiryczne - polegające na utrzymaniu stałego zasobu kapitału naturalnego. ${ }^{5}$

Zatem celem rozwoju zrównoważonego będzie taki rozwój gospodarki i społeczeństwa, który nie doprowadzi do zmian w środowisku tam, gdzie jego stan jest dobry lub gdy stan środowiska jest zły, pozwoli na jej rozwój przy jednoczesnym jego poprawieniu.

Obserwacja i reakcja na ciągłe zmiany zachodzące w zasobach nieruchomości umożliwi osiągnięcie tego celu.

\section{Wykorzystanie wskaźników zrównoważonego rozwoju przy podejmowaniu decyzji istotnych dla ograniczonych dóbr naturalnych}

Jednym z narzędzi informacyjno-diagnostycznych są wskaźniki zrównoważonego rozwoju. Badania przeprowadzane $\mathrm{w}$ ramach systemu analiz samorządowych są bardzo użyteczne w sporządzaniu strategii rozwoju jednostek samorządu terytorialnego.

T. Borys pogrupował te wskaźniki według ładu: 1) środowiskowo-przestrzennego (w skład którego wchodzą następujące dziedziny: ekologizacji planowania przestrzennego, ochrona przyrody i krajobrazu, ochrona i zrównoważony rozwój lasów, ochrona gleby, ochrona zasób kopalin, ochrona wód i powietrza, energia odnawialna i bezpieczeństwo biologiczne, chemiczne, elektromagnetyczne i przeciwdziałanie skutkom awarii przemysłowych); 2) gospodarczego (w skład którego wchodzą następujące dziedziny: finanse gminy, przedsiębiorczość, struktura podmiotów gospodarczych, poziom i struktura zatrudnienia, budownictwo mieszkalne, 
rolnictwo, turystyka, infrastruktura techniczna, wykorzystanie materiałów i surowców oraz dostępność do produktów i usług); 3) społecznego (w skład którego wchodzą następujące dziedziny: demografia, edukacja, pomoc społeczna, zdrowie, bezpieczeństwo publiczne, mieszkalnictwo, kultura, sport i rekreacja, partycypacja społeczna, aktywność na rynku pracy oraz ład instytucjonalno-polityczny). ${ }^{6}$

Ważnym aspektem rozwoju zasobów nieruchomości powinno być uwzględnienie kosztów środowiskowych przy konkurencyjności przedsiębiorstw, które realizują te inwestycje.

\section{Panowanie przestrzenne przy uwzględnieniu zasady zrównoważonego rozwoju}

Przestrzeń oddziałuje na człowieka w bardzo dużym stopniu. Wpływa bowiem na nastój, zachowanie, podejmowane decyzje czy poczucie bezpieczeństwa. ${ }^{7}$

Jak podkreśla K. Wejchert: „dla człowieka niezbędne jest środowisko przestrzenne nie tylko dobrze zorganizowane, prawidłowo funkcjonujące, lecz dostarczające mu przeżyć estetycznych zawierających w sobie różne nastroje, poezję, symbolikę, oprawę dla cennych tradycji, pozwalające na mocny związek jednostki z miastem, jego dzielnicą lub regionem". 8

Zgodnie z tezą wygłoszoną przez Z. Niewiadomskiego, „gospodarowanie przestrzenne jest procesem $z$ natury konfliktogennym. Jest grą wielu podmiotów o sprzecznych interesach. Zadaniem regulacji prawnych jest próba godzenia tych interesów. To zaś oznacza, że prawo zagospodarowania przestrzennego staje się wyrazem kompromisu pomiędzy różnymi interesami i wyobrażeniami o zagospodarowaniu przestrzenią i jako takie nie zadowala na ogół nikogo. Budzi skrajne emocje i oceny". 9

Polityka rozwoju mieszkalnictwa z punktu widzenia planistycznego oznacza konieczność sporządzania i aktualizacji koncepcji przestrzennego zagospodarowania kraju, strategii rozwoju województw, studiów uwarunkowań i kierunków zagospodarowania przestrzennego gmin oraz miejscowych planów zagospodarowania przestrzennego.

W studium uwarunkowań i kierunków zagospodarowania przestrzennego gmin oraz miejscowych planów zagospodarowania przestrzennego zapewnia się warunki utrzymania równowagi przyrodniczej i racjonalną gospodarkę zasobami środowiska. Zatem ustalenie planu stanowi podstawę do podejmowania decyzji o przeznaczeniu

T. Borys, Zaprojektowanie i przetestowanie ram metodologicznych oraz procedury samooceny gmin na podstawie wskaźników zrównoważonego rozwoju w Systemie Analiz Samorządowych /SAS/, Raport dla ZMP, Jelenia Góra-Poznań 2008.

7 P.A. Bell Greene Th., J.D. Fisher, A. Baum, Psychologia środowiskowa, Gdańsk 2004.

8 K. Wejchert, Elementy kompozycji urbanistycznej, Warszawa 1984, s. 93.

9 Z. Niewiadomski, Komentarz. Planowanie i zagospodarowanie przestrzenne, Warszawa 2006, s. VII. 
terenu, zapewniając warunki utrzymania równowagi przyrodniczej oraz gospodarki zasobami środowiska. Jednakże nie wszystkie miasta mają uchwalone plany zagospodarowania przestrzennego.

$\mathrm{Na}$ obszarach pozbawionych planów zagospodarowania przestrzennego obowiązuje procedura wydawania doraźnych decyzji ustalających warunki zabudowy i zagospodarowania terenu. Brak miejscowych planów zagospodarowania przestrzennego zauważalny jest przede wszystkim w dużych miastach, gdzie plany uchwalane są fragmentarycznie dla poszczególnych obszarów miasta. To rozdrobnienie planistyczne skutkuje bardzo często pominięciem aspektów związanych z programami ochrony środowiska.

$\mathrm{Z}$ brzmienia przepisu art. 1 ustawy z dnia 27 marca 2003 r. o planowaniu i zagospodarowaniu przestrzennym wynika, że ustawa ma służyć przede wszystkim zapewnieniu możliwości wprowadzenia do gospodarki przestrzennej ładu przestrzennego (a zatem pewnych z góry określonych zasad) zapewniającego harmonię między zabudową już istniejącą a planowaną. ${ }^{10}$ Ład przestrzenny i zrównoważony rozwój uznane zostały przez ustawodawcę za podstawy działań w zakresie planowania i zagospodarowania przestrzennego.

Zatem przez zrównoważony rozwój należy rozumieć taki rozwój społecznogospodarczy, w którym następuje proces integrowania działań politycznych, gospodarczych i społecznych z zachowaniem równowagi przyrodniczej oraz trwałości podstawowych procesów przyrodniczych w celu zagwarantowania możliwości zaspokajania podstawowych potrzeb poszczególnych społeczności lub obywateli zarówno współczesnego pokolenia, jak i przyszłych pokoleń.

Z kolei, definicja ustawowa „ładu przestrzennego” wskazuje, że należy rozumieć pod tym pojęciem takie ukształtowanie przestrzeni, które tworzy harmonijną całość oraz uwzględnia w uporządkowanych relacjach wszelkie uwarunkowania i wymagania funkcjonalne, społeczno-gospodarcze, środowiskowe, kulturowe oraz kompozycyjno-estetyczne.

Niestety w obecnych realiach wyżej wskazane determinanty, które winny stanowić podstawę polityki przestrzennej, są często bagatelizowane. Niejednokrotnie inwestorzy wykorzystując luki w prawie, niejasne pojęcia ustawowe uzyskują decyzje administracyjne, w których organy administracji ustalają warunki zabudowy dla danego terenu, nie zastanawiając się, jakie będą tego skutki w przyszłości. Przykładowo nowa zabudowa jest dopuszczalna tylko wtedy, gdy można ją pogodzić z istniejącą funkcją danego terenu.

Rozumienie pojęcia „kontynuacja funkcji zabudowy i zagospodarowania terenu" należy traktować szeroko - zgodnie z wykładnią systemową, która nakazuje rozstrzygać wątpliwości na rzecz uprawnień właściciela czy inwestora po to, aby 
mogła być zachowana wynikająca z art. 6 ust. 2 powołanej ustawy o planowaniu i zagospodarowaniu przestrzennym zasada wolności w zagospodarowaniu terenu, w tym jego zabudowy. ${ }^{11}$ Należy mieć na względzie, że procedura wydawania decyzji ustalających warunki zabudowy zamyka się w dokonaniu analizy parametrów w określonym obszarze, którego niestety zakres jest ograniczony.

Władze w swoich decyzjach administracyjnych ustalających warunki zabudowy kierują się raczej zasadą ekonomiczną, a nie zasadą zrównoważonego rozwoju (przykładem może być likwidacja terenów zielonych, parków itp.).

Dlatego niekontrolowany rozwój miast skutkujący w znacznym stopniu zniweczeniem równowagi pomiędzy zabudową mieszkaniową a infrastrukturą zieloną i obszarami biologicznie czynnymi może zostać zahamowany wyłącznie wskutek uchwalenia miejscowych planów zagospodarowania przestrzennego.

Decyzje dotyczące warunków zabudowy odnoszą się tylko do określonych obszarów. Takie ograniczenie uniemożliwia spojrzenie globalnie na dany obszar, również w perspektywie czasu. Taka sytuacja w konsekwencji prowadzi do nieodwracalnych skutków zniszczeń środowiska naturalnego i zaburzenia istniejącego ekosystemu.

Nie ulega zatem wątpliwości, że wprowadzenie zasad zrównoważonego rozwoju w plany zagospodarowania przestrzennego jest bardzo ważne. Tylko w ten sposób zapobiegnie się nieodwracalnej degradacji środowiska.

\section{Podsumowanie}

Prawidłowe zarządzanie w zakresie utrzymania zrównoważonego rozwoju będzie polegać na ustaleniu i przyjęciu strategii pozwalającej na realne wdrożenie, realizację i kontrolę procesu. Takie podejście jest uzasadnione nie tylko pod względem ekologicznym, ale również ekonomicznym. Trzeba zwrócić szczególną uwagę na fakt, że dzisiejsze decyzje w zakresie zarządzania istniejącymi i ograniczonymi zasobami będą bezpośrednio wpływać na przyszłe pokolenia.

Zatem plany zwiększenia zasobów nieruchomości powinny nastąpić na poziomie świadomości kosztów ekologicznych. Właściwa implikacja zasad teorii zrównoważonego rozwoju może okazać się największym i najważniejszym instrumentem rozwoju rynku nieruchomości w Polsce.

Należy mieć bowiem na uwadze, że rynek nieruchomości jest ściśle związany z gospodarką każdego państwa. Sytuacja gospodarcza danego regionu, w kraju decyduje o sytuacji na rynku nieruchomości. Z drugiej strony rynek nieruchomości wpływa w pośredni sposób na rozwój gospodarczy państwa i jego poszczególnych regionów. Uświadomienie sobie tego faktu wraz z wiedzą o ograniczonych zasobach

11 Por. wyrok WSA w Warszawie z dnia 23 października 2006 r., sygn. akt IV SA 482/06, niepubl. 
naturalnych jest fundamentem do osiągnięcia wysokiego rozwoju społeczno-gospodarczego każdej gospodarki.

Budownictwo jest bowiem działem gospodarki, w którym wzrost zatrudnienia przy budowie mieszkań powoduje wzrost zatrudnienia w przemysłach pracujących na rzecz budownictwa i wyposażenia mieszkań. ${ }^{12}$

Należy bowiem mieć na uwadze, że środki publiczne przeznaczone na budownictwo mieszkaniowe - poza rozwiązaniem ważnych problemów społecznych przynoszą realne wpływy do budżetu państwa. ${ }^{13}$

\section{BIBLIOGRAFIA}

Bell P.A., Greene Th., Fisher J.D., Baum A., Psychologia środowiskowa, Gdańsk 2004.

Borys T., Wskaźniki ekorozwoju, „Ekonomia i Środowisko” 1999, nr 1.

Borys T., Zaprojektowanie i przetestowanie ram metodologicznych oraz procedury samooceny gmin na podstawie wskaźników zrównoważonego rozwoju w Systemie Analiz Samorządowych (SAS), Raport dla ZMP, Jelenia Góra-Poznań 2008.

Dobrzański G., Istota i cechy współczesnego kryzysu ekologicznego, „Ekonomia i Środowisko” 1999, nr 14.

Encyklopedia wiedzy o nieruchomościach, Baranowski W., Buczek G., Chełmiński B., Jurek K., Kozłowski E., Nalepka A., Rogatko B., Schmidt J. (red.), Warszawa-Kraków 2008.

Konkurencyjność sektora budowlanego w krajach EU, Komisja Wspólnot Europejskich, Bruksela, COM /97/, 1997.

Korecki W., Rydzyk W., Kałkowski L., Związki budownictwa mieszkaniowego z gospodarką narodową, Warszawa 1994.

Machaczka J., Podstawy zarządzania, Kraków 1999.

Niewiadomski Z., Komentarz. Planowanie i zagospodarowanie przestrzenne. Warszawa 2006.

Wejchert K., Elementy kompozycji urbanistycznej, Warszawa 1984.

Zegar J.S., Kierowanie zrównoważonym rozwojem społeczno-gospodarczym (ekorozwojem), ,Monografie i Opracowania” 2003, nr 522.

12 Konkurencyjność sektora budowlanego w krajach EU, Komisja Wspólnot Europejskich, Bruksela, COM /97/, 1997.

13 W. Korecki, W. Rydzyk, L. Kałkowski, Związki budownictwa mieszkaniowego z gospodarką narodową, Warszawa 1994, s. 29. 


\section{MANAGEMENT OF REAL ESTATE IN THE PROCESS OF IMPLEMENTING SUSTAINABLE DEVELOPMENT}

The residential real estate market is capital intensive, which is causing very strong economic ties with attendant conflicting interests amongst its various participants. Taking this into consideration, housing policy decisions must therefore be comprehensive and versatile, otherwise negative effects may arise that become greater than scheduled benefits. The current market situation should be seen in the light of creating social and environmental crisis. This is because the availability of limited natural resources may ultimately serve to inhibit economic and social development and lead to the generation of irreversible processes. This is why sustainable development is such an important consideration in the problematic area of real estate resource efficiency.

Key words: management, sustainable development, real estate, natural resources, spatial planner 